$\left.\begin{array}{c}\text { BIODIK: Jurnal IImiah Pendidikan Biologi } \\ \text { ISSN 2580-0922 (online), ISSN 2460-2612 (print) } \\ \text { Volume 07, Nomor 03, Tahun 2021, Hal. 164-175 } \\ \text { Available online at: } \\ \text { hIttps://online-journal.unja.ac.id/biodik }\end{array}\right)$ BIODIK

Research Article

OPEN ACCESS

\title{
Profil Keterampilan Proses Sains Peserta Didik Menggunakan Model Pembelajaran 9E Learning Cyccle at Home Melalui Pembelajaran Daring
}

\section{(Profile of Students' Science Process Skills Using the 9E Learning Cycle at Home Learning Model Through Online Learning)}

\author{
Dissa Thami Putri*, Setiono, Billyardi Ramadhan
}

Program Studi Pendidikan Biologi

Fakultas Keguruan dan IImu Pendidikan, Universitas Muhammadiyah Sukabumi J. R. Syamsudin, S.H. No.50, Cikole, Kec. Cikole, Kota Sukabumi, 43113, Indonesia

*Corresponding author: dissa008@ummi.ac.id

\begin{tabular}{|c|c|}
\hline Informasi Artikel & ABSTRACT \\
\hline $\begin{array}{l}\text { Submit: } 01-07-2021 \\
\text { Diterima: } 28-08 \text { - } 2021 \\
\text { Dipublikasikan: } 30-09-2021\end{array}$ & $\begin{array}{l}\text { This study aims to analyze the science process skills of students before and after } \\
\text { the application of the } 9 E \text { Learning cycle at home model through online learning } \\
\text { on the subject of environmental pollution. This research uses an experimental } \\
\text { method and this type of reseach uses a pre-experimental design. The instrument } \\
\text { used was a science process skills test in the form of } 14 \text { multiple choice questions } \\
\text { with } 6 \text { indicators of science process skills, namely 1) observing, 2) classifying, 3) } \\
\text { measuring, 4) communicating, 5) concluding, 6) predicting. The population in this } \\
\text { study was class VII semester } 2 \text { MTs Persatuan Islam Academic Year 2020/2021, } \\
\text { with } 21 \text { female and } 7 \text { male students. The results showed that there was a } \\
\text { significant difference in the students scicence process skills from before and } \\
\text { after the } 9 E \text { Learning Cycle at Home model was applied through online learning. } \\
\text { The average percentage of N-Gain in increasing the achievement of students } \\
\text { science process skills, which is } 84 \% \text {, is included in the high category. The } \\
\text { highest percentage of N-Gain is obtained in indicator 4, which is } 97 \% \text {, while the } \\
\text { lowest is in indicator } 2 \text {, which is } 71 \% \text {, and the science process skills achieved by } \\
\text { female students are superior to men, namely } 94 \%: 90 \% \text {. This shows that learning } \\
\text { about environmental pollution using the } 9 E \text { learning cycle at home model through } \\
\text { online learning can improve students science process skills and is useful for the } \\
\text { continuity of the learning process. } \\
\text { Key words: } 9 E \text { Learning ciycle, science process skils, online learning }\end{array}$ \\
\hline Penerbit & ABSTRAK \\
\hline $\begin{array}{l}\text { Program Studi Pendidikan Biologi } \\
\text { FKIP Universitas Jambi, } \\
\text { Jambi- Indonesia }\end{array}$ & $\begin{array}{l}\text { Penelitian ini bertujuan untuk menganalisis keterampilan proses sains peserta } \\
\text { didik sebelum dan setelah penerapan model } 9 E \text { Eearning Cycle at Home melalui } \\
\text { pembelajaran daring pada pokok bahasan pencemaran lingkungan. Penelitian } \\
\text { ini menggunakan metode eksperimen dan jenis penilitiannya menggunakan pre- } \\
\text { eksperimental design. Instrumen yang digunakan adalah tes keterampilan } \\
\text { proses sains berupa soal pilihan ganda sebanyak } 24 \text { soal dengan } 6 \text { indikator } \\
\text { keterampilan proses sains yaitu 1) Mengamati, 2) Mengklasifikasi, 3) Mengukur, } \\
\text { 4) Mengomunikasikan, 5) Menyimpulkan, 6) Memprediksi. Populasi dalam } \\
\text { penelitian ini adalah kelas VII semester } 2 \text { MTs Persatuan Islam Tahun Ajaran } \\
2020 / 2021 \text {, dengan peserta didik berjumlah } 21 \text { orang perempuan dan } 7 \text { orang laki- } \\
\text { laki. Hasil penelitian bahwa adanya perbedaan signifikan terhadap } \\
\text { keterampilan proses sains peserta didik dari sebelum dan setelah diterapkan } \\
\text { model } 9 E \text { Learning Cycle at Home melalui pembelajaran daring. Rata-rata } \\
\text { persentase N-Gain peningkatan ketercapaian keterampilan proses sains peserta }\end{array}$ \\
\hline
\end{tabular}


didik yaitu $84 \%$ termasuk dalam kategori tinggi. Persentase $\mathrm{N}$-Gain tertinggi didapat pada indicator 4 yaitu sebesar $97 \%$ sedangkan terendah pada indicator 2 yaitu $71 \%$, dan keterampilan proses sains yang dicapai peserta didik perempuan lebih unggul dari laki-laki yaitu $94 \%: 90 \%$. Hal ini menunjukkan dalam pembelajaran pada materi pencemaran lingkungan menggunakan model 9E Learning Cycle at Home melalui pembelajaran daring dapat meningkatkan keterampilan proses sains peserta didik dan berguna untuk keberlangsungan proses pembelajaran.

Kata kunci: $9 E$ learning cycle, keterapilan proses sains, pembelajaran daring

This BIODIK : Jurnal IImiah Pendidikan Biologi is licensed under a CC BY-NC-SA (Creative Commons Attribution-ShareAlike 4.0 International License)

\section{PENDAHULUAN}

Pendidikan merupakan proses pembelajaran pengetahuan, keterampilan, serta kebiasaan yang di lakukan suatu individu dari satu generasi ke generasi lainnya (Niko Ramdhani, 2020). Pembelajaran adalah proses untuk membantu peserta didik agar dapat belajar dengan baik. Pelaksanaan proses pembelajaran masih sering ditemui adanya kecenderungan meminimalkan keterlibatan peserta didik. Oleh karena itu, perlu adanya suatu perubahan strategi pembelajaran yaitu pembelajaran yang berpusat pada guru (teacher centered) menjadi pembelajaran yang berpusat pada peserta didik (student centered) (Ganda Noor Andaru, M. Rendi Astono Sentosa, 2019). Pengalaman belajar menjadi salah satu penentu keberhasilan proses konstruksi pengetahuan yang dilakukan oleh peserta didik (Setiono et al., 2019). Pendekatan, metode dan strategi pembelajaran sangat berperan penting dalam proses pembelajaran terutama dalam membantu menyampaikan informasi (Lesmana Sari et al., 2020).

Keterampilan proses sains merupakan keterampilan yang memfasilitasi pembelajaran sains sehingga memungkinkan peserta didik untuk aktif dalam memecahkan masalah dan mengembangkan rasa tanggung jawab. Keterampilan proses ilmiah penting dimiliki setiap individu sebab keterampilan tersebut digunakan dalam kehidupan sehari-hari dan meningkatkan kemampuan ilmiah (Andani \& Utami, 2019). Ketika peserta didik mampu memahami konsep, mengembangkan rasa ingin tahu, memiliki keterampilan proses dan mampu memecahkan permasalahan menggunakan pemahaman yang telah dimiliki maka dapat dikatakan peserta didik sudah memiliki kemampuan berpikir kritis (Dewi et al., 2017).

Berdasarkan hasil observasi dan wawancara yang dilakukan dengan guru IPA di MTs Persatuan Islam 4 Cianjur pada bulan November 2020, ditemukan bahwa pembelajaran di masa pandemi covid-19 memberikan banyak pengaruh khususnya pada keterampilan proses sains peserta didik. Hal tersebut disebabkan karena beberapa faktor diantaranya pembelajaran menggunakan metode konvensional dengan tatap muka hanya seminggu sekali dan kurangnya kegiatan pembelajaran yang membekalkan keterampilan proses, pembelajaran juga tidak menggunakan media-media pendukung yang membekalkan keterampilan proses khususnya pada pembelajaran daring. Menurut Nurmiati (2020) dalam (Gusty, 2020) siap atau tidak, dunia pendidikan harus melakukan proses pembelajaran daring bersadarkan surat edaran Menteri Pendidikan dan Kebudayaan Republik Indonesia, Nomor 4 Tahun 2020 tentang Pelaksanaan Kebijakan Pendidikan dalam Masa Darurat Penyebaran covid-19. Sistem pembelajaran dilaksanakan melalui perangkat personal komputer (PC) atau laptop yang terhubung dengan koneksi jaringan internet. (Kemendikbud, 2020). 
Berdasarkan pertimbangan di atas, maka perlu adanya penerapan suatu model pembelajaran yang diharapkan dapat meningkatkan keterampilan proses sains melalui pembelajaran daring untuk menunjang proses belajar mengajar di masa pandemi covid-19. Salah satu model pembelajaran yang dinilai dapat memfasilitasi keterampilan proses sains adalah model $9 E$ learning cycle at home. Model learning cycle (siklus belajar) adalah rangkaian tahap-tahap kegiatan (fase) yang diorganisasi sedemikian rupa sehingga pebelajar dapat menguasai kompetensi-kompetensi yang harus dicapai dalam pembelajaran dengan jalan berperanan aktif (Ngalimun dalam Adilah \& Budiharti, 2015). Slavin dalam (Adilah \& Budiharti, 2015) menjelaskan bahwa menurut pandangan konstruktivisme anak secara aktif membangun pengetahuan dengan cara terus menerus mengasimilasi dan mengakomodasi informasi baru, dengan kata lain konstruktivisme adalah teori perkembangan kognitif yang menekankan peran aktif siswa dalam membangun pemahaman mereka tentang realita. Selain berbasis konstruktivisme, learning cycle juga sesuai dengan teori belajar Piaget atau yang dikenal dengan teori perkembangan kognitif Piaget.

Model Pembelajaran 9E Learning Cycle menurut Kaur (Buwono et al., 2020), terdiri dari 9 sinteks diantaranya: (1) Elicitation, (2) Engagement, (3) Exploration, (4) Explanation, (5) Echo, Exploration dan Explanation. (6) Elaboration, (7) Evaluation, (8) Emendation, (9) E-Search. Model $9 E$ learning cycle at home dinilai dapat membekalkan keterampilan proses sains peserta didik saat pembelajaran melalui langkah-langkah kegiatan pembelajaran yang dilakukan. Hal tersebut diketahui dari beberapa keterbaruan penelitian mengenai model learning cycle diantaranya penelitian yang dilakukan oleh Izzah Imaniyah, Siswoyo dan Fauzi Bakri pada tahun 2015 diketahui bahwa dalam pembelajaran pada kelas ekperimen dengan menggunakan model pembelajaran learning cycle terlihat peserta didik lebih semangat mengikuti pembelajaran karena dikaitkan dengan fenomena sehari-hari, peserta didik mengetahui aplikasi dari konsep yang ada, peserta didik menjadi lebih mengetahui contoh soal yang digunakan. Selanjutnya penelitian yang dilakukan oleh Tukiran, Fitroh A. Mubarokah danHarun Nasrudin Dengan menggunakan model siklus pembelajaran 9E yang diterapkan pada siswa di SMAN 7 Surabaya menunjukkan adanya peningkatan motivasi, dan hasil belajar bagi mereka (Tukiran et al., 2020). Berdasarkan dari uraian diatas maka dilakukan penelitan untuk mengetahui kemampuan keterampilan proses sains peserta didik kelas VII menggunakan model 9E learning cycle at home melalui pembelajaran daring.

\section{METODE PENELITIAN}

Metode yang di gunakan dalam penelitian ini adalah pre experimental design. Desain penelitian yang digunakan adalah one-group pretest posttesst design, yaitu pengambilan satu kelompok atau kelas yang diberkan pra dan pasca uji. Rancangan one-group pretest posttest design ini dilakukan pada satu kelompok tanpa adanya kelompok kontrol atau pembanding (Sugiyono, 2018). Populasi yang digunakan pada penelitian ini yaitu siswa kelas VII pada salah satu SMP di Kota Cianjur pada tahun ajaran 2020/2021. Sedangkan sampel yang digunakan sebanyak 28 peserta didik terdiri dari 21 perempuan dan 7 laki-laki yang diperoleh dengan teknik purposive sampling yaitu pengambilan sample yang di dasarkan pada pertimbangan tertentu (Sugiyono, 2018). Penelitian dilakukan pada bulan April 2021. Pengumpulan data dilakukan dengan menggunakan Instrumen soal tes keterampilan proses sains berupa pilihan ganda sebanyak 24 soal dengan 6 indikator keterampilan proses sains. Adapun kategori presentae keterampilan proses sains dapat dilihat pada tabel 1. 
Tabel 1. Persentase Kategori Keterampilan Proses Sains

\begin{tabular}{cc}
\hline Persentase (\%) & Kategori \\
\hline $86-100$ & Sangat Baik \\
$76-85$ & Baik \\
$60-75$ & Cukup \\
$55-59$ & Kurang \\
$\leq 54$ & Kurang Sekali \\
\hline
\end{tabular}

\section{HASIL PENELITIAN DAN PEMBAHASAN}

Menurut Science-A Process Approach (SAPA) (Ai Hayati Rahayu \& Poppy Anggraeni, 2017) keterampilan proses sains ini didefinisikan sebagai seperangkat kemampuan yang dapat dipindahtangankan secara luas, sesuai dengan banyak disiplin sains dan mencerminkan perilaku ilmuwan. Dash dan Padhi (Rahmah et al., 2019) mengungkapkan bahwa keterampilan proses sains merupakan kemampuan peserta didik dalam memahami, menemukan dan mengembangakan ilmu pengetahuan melalui metode ilmiah sebagaimana ilmuan menemukan konsep. Keterampilan proses sains yang diukur pada penelitian ini terdiri atas enam indicator. Hasil uji statistik skor keterampilan proses sains menggunakan model $9 E$ learning cycle at home disajikan pada tabel 2.

Tabel 2. Hasil Uji Statistik Keterampilan Proses Sains Descriptive Statistics

\begin{tabular}{cc|c|c|c|c} 
N & Minimum & Maximum & Mean & Std. Deviation \\
\hline & & & & & \\
\hline Pre Test & 28 & 25 & 92 & 54.91 & 18.533 \\
\hline Post Test & 28 & 79 & 100 & 93.01 & 6.420 \\
\hline Valid N (listwise) & 28 & & & & \\
\hline
\end{tabular}

Tabel 2 menunjukan nilai Pada pre-test didapatkan skor minimum yaitu 25 dan skor maximum 92 serta nilai mean yaitu 54,91, sementara pada post-test didapatkan skor minimum 79 dan skor maximum 100 serta nilai mean 93,01. Hasil Penelitian pada tabel 2 menunjukan uji statistik deskriptif yang memuat nilai maksimum, minumum dan mean.

Tabel 3. Hasil tes keterampilan proses sains setiap indikator

\begin{tabular}{ccccc}
\hline \multirow{2}{*}{ No } & Indikator Keterampilan ProsesSains & \multicolumn{2}{c}{ Presentase Ketercapaian (\%) } & \multirow{2}{*}{ Kategori Hasil Postest } \\
\cline { 3 - 4 } & & Pre-Test & Post-Test & \\
\hline 1. & Mengamati & $59 \%$ & $95 \%$ & Sangat baik \\
2. & Mengklasifikasi & $55 \%$ & $87 \%$ & Sangat Baik \\
3. & Mengukur & $60 \%$ & $90 \%$ & Sangat baik \\
4. & Mengomunikasikan & $54 \%$ & $99 \%$ & Sangat Baik \\
5. & Menyimpulkan & $58 \%$ & $95 \%$ & Sangat Baik \\
6. & Memprediksi & $54 \%$ & $94 \%$ & Sangat Baik \\
\hline
\end{tabular}


Tabel 3 merupakan hasil keterampilan proses sains pada saat pre-tets dan posttest. Pretest memiliki nilai rata- rata $57 \%$ yang termasuk dalam kategori kurang dan terjadi peningakatan pada saat posttest yaitu menjadi 93\% yang termasuk dalam kategori sangat baik. Berdasarkan pada tabel 3 dan gambar pada grafik menunjukkan adanya perbedaan yang signifikan pada skor pre-test dan post-tes. Peserta didik memiliki nilai yang lebih tinggi pada saat post-test dibandingkan dengan nilai pre-test. Hal ini memungkinkan karena pada saat proses pembelajaran berlangsung menggunakan model $9 E$ learning cycle at home. Peserta didik mendapatkan pengalaman belajar yang lebih bermakna sehingga melatih keterampilan proses sains peserta didik.

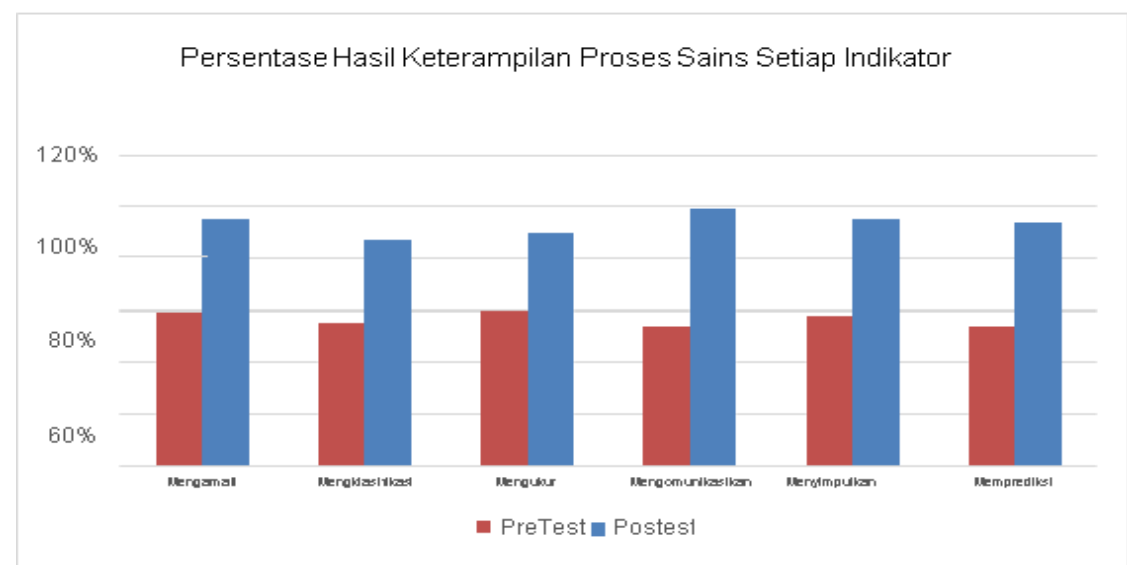

Gambar 1. Persentase Hasil Keterampilan Proses Sains Setiap Indikator

Pada gambar 1 dapat dilihat persentase hasil keterampilan proses sains setiap indikator. Indicator keterampilan proses sains meliputi mengamati, mengklasifikasi, mengukur, mengkomunikasikan, mengumpulkan dan memprediksi.

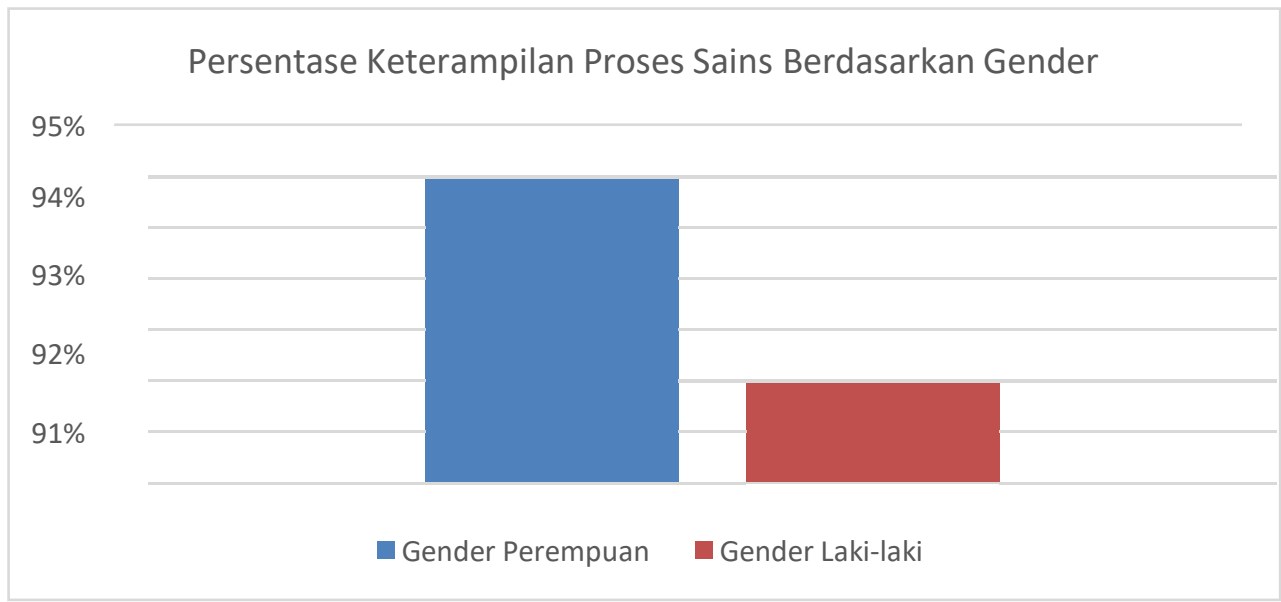

Gambar 2. Persentase Keterampilan Proses Sains Berdasarkan Gender

Dari gambar 2 dapat diperoleh informasi bahwa persentase keterampilan proses sains dapat dibagi menjadi dua berdasarkan gender. Pada gender perempuan diperoleh persentase $94 \%$ dan pada gender laki-laki diperoleh persentase $91 \%$. Persentase keterampilan proses sains gender perempuan lebih besar dari gender laki-laki. 


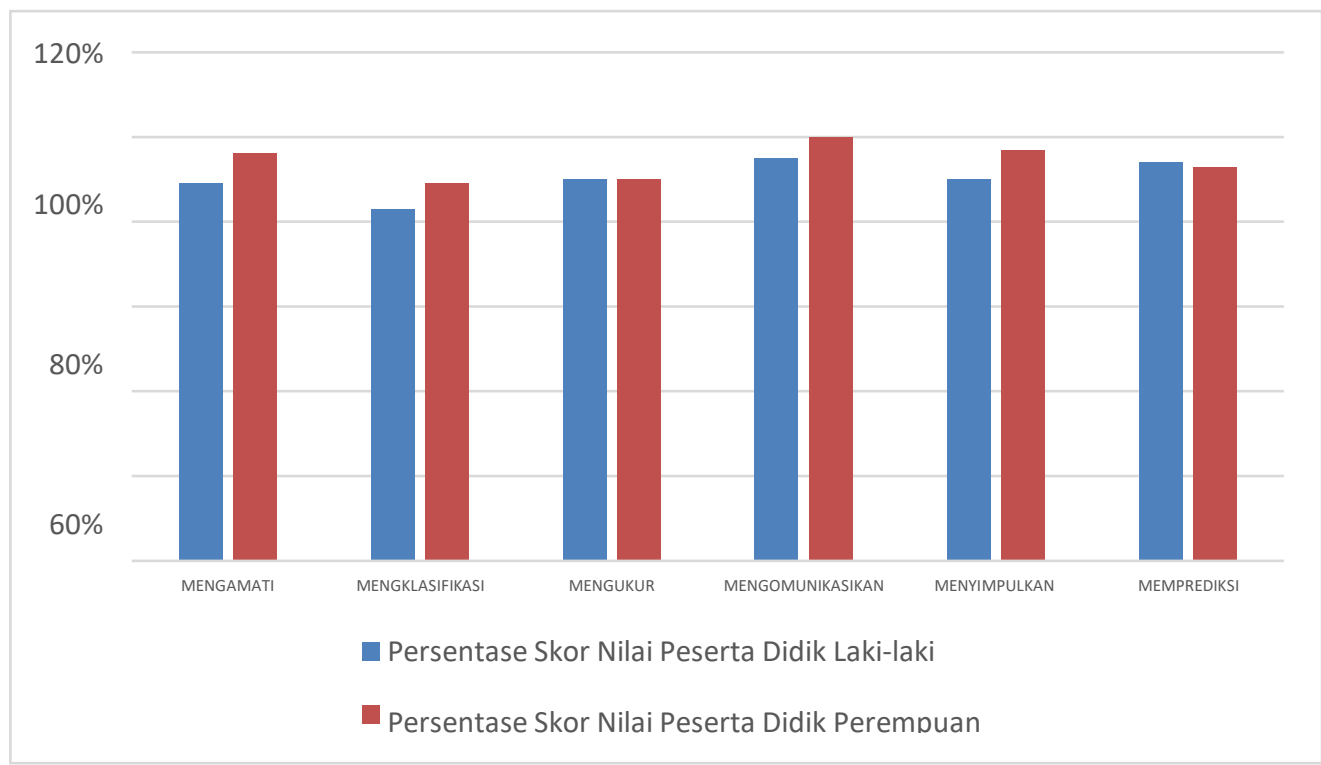

Gambar 3. Persentase Keterampilan Proses Sains Per Indikator Berdasarkan Gender

Indikator keterampilan proses sains dasar menurut Hartono (A Mulyana, 2020) meliputi : 1) mengamati, 2) mengklasifikasikan, 3) mengukur, 4) mengomunikasikan, 5) menarik kesimpulan, 6) memprediksi. Melihat grafik pada gambar $1 \mathrm{di}$ atas, perolehan nilai posttest pada indikator 1 yaitu mengamati terjadi peningkatan ketercapaian dengan nilai presentase sebesar $95 \%$ yang termasuk kedalam kategori sangat baik, pada indikator 2 yaitu mengklasifikasi dengan nilai presentase sebesar $87 \%$ yang termasuk dalam kategori sangat baik, indikator 3 yaitu mengukur terjadi peningkatan dengan nilai presentase sebesar $90 \%$ yang termasuk dalam kategori sangat baik, indikator 4 mengkomunikasikan terjadi peningkatan dengan nilai presentase sebesar $99 \%$ yang termasuk dalam sangat baik, indikator 5 yaitu menyimpulkan dengan nilai presentase sebesar $95 \%$ yang termasuk dalam kategori sangat baik dan indicator 6 yaitu memprediksi terjadi peningkatakan dengan nilai persetase $94 \%$. Ratarata persentase ketercapaian keterampilan proses sains peserta didik yaitu $93 \%$ yang termasuk dalam kategori sangat baik. Hal ini menunjukkan bahwa penerapan model $9 E$ learning cycle at home memiliki efek positif terhadap keterampilan proses sains peserta didik. Pada indikator 1 yaitu mengamati, peserta didik belajar keterampilan proses sains secara bertahap melalui pengumpulan informasi melalui penggunaan salah satu, atau kombinasi dari lima indra dasar; penglihatan, pendengaran, sentuhan, rasa, dan bau (Ai Hayati Rahayu \& Poppy Anggraeni, 2017), pada indikator 2 meminta peserta didik untuk mengklasifikasi, pada indikator 3 peserta didik melakukan pengukuran, pada indikator ke 4 yaitu mengkomunikasikan, hampir seluruh peserta didik sudah mampu untuk menafsirkan data sehingga masuk dalam kategori sangat baik, pada indikator 6 peserta diminta untuk menyimpulkan dan pada indicator 6 peserta didik diminta untuk memprediksi, soal yang diberikan pada indikator ini yaitu berkaitan dengan memproyeksikan kejadian berdasarkan sekumpulan informasi. 
Pada tabel 3 yaitu menunjukan N-Gain dari setiap indikator, perolehan N-Gain terbesar terdapat pada indikator 4 yaitu dengan nilai 0,97 termasuk ke dalam kategori tinggi, lalu pada indikator 5 dengan nilai 0,89 termasuk dalam kategori tinggi, indikator 1 dan 6 dengan nilai 0,86 termasuk ke dalam kategori tinggi, indicator 3 dengan nilai 0,76 termasuk ke dalam kategori tinggi dan indikator 2 dengan nilai 0,71 juga masih termasuk dalam kategori tinggi. Berdasarkan dari hasil pada table 4 telah menunjukkan bahwa penerapan model $9 E$ learning cycle bisa secara signifikan meningkatkan hasil belajar peserta didik ( $\mathrm{S}$ a $\mathrm{r}$ a ç , 2018 ) dan dapat pula meningkatkan keterampilan proses sains (Suardana et al., 2018), dan dapat pula meningkatkan sikap ilmiah peserta didik (Sayuti et al., 2013). Model siklus belajar sangat erat kaitannya dengan teori konstruktif (Yaman \& Karaşah, 2018). Model siklus pembelajaran 9E juga mendukung kemampuan intelektual siswa (P. Kaur \& A. Gakhar, 2014). Hasil tertinggi pada aspek mengkomunikasikan dikarenakan peserta didik memiliki kemampuan yang baik dalam membaca data baik berupa tabel maupun grafik (Nirmalasari, Santiani, 2016).

Pada gambar 2 yaitu grafik keterampilan proses sains peserta didik laki-laki dan perempuan keduanya masuk ke dalam kategori sangat baik. Peserta didik perempuan lebih unggul dari laki-laki yaitu dengan presentase sebesar $94 \%$ sedangkan peserta didik laki-laki sebesar $90 \%$. Pada gambar 3 yaitu menunjukkan keterampilan proses sains peserta didik laki-laki dan perempuan di setiap indikator. Pada indikator 1 peserta didik perempuan lebih unggul dengan nilai presentase 96\% termasuk dalam kategori sangat baik dan laki-laki memiliki nilai presentase $89 \%$ termasuk juga dalam kategori sangatbaik, karena peserta didik perempuan realif lebih mampu mengamati soal yang diberikan sehingga skor yang didapat lebih tinggi. Pada indikator 2 peserta didik laki-laki memiliki nilai persentase 83\% termasuk ke dalam kategori baik dan peserta didik perempuan memiliki nilai $89 \%$ yang masih mengungguli peserta didik laki-laki dengan kategori sangat baik. Pada indikator 3 peserta didik laki-laki dan perempuan memiliki nilai presentase yang sama yaitu $90 \%$ termasuk dalam kategori sangat baik, pada indikator 4 peserta didik lakilaki memiliki nilai $95 \%$ dan peserta didik perempuan memiliki nilai sempurna yaitu $100 \%$, keduanya masuk ke dalam kategori sangat baik. Pada indikator 5 peserta didik laki-laki memiliki nilai presentase $90 \%$ termasuk dalam kategori sangat baik dan peserta didik perempuan nilainya lebih besar yaitu $97 \%$ juga termasuk dalam kategori baik. Pada indicator 6 peserta didik laki-laki memiliki nilai 94\% yang lebih tinggi dibandingkan peserta didik perempuan walaupun perbedaannya hanya sedikitsedangkan perempuan memiliki nilai 93, keduanya masuk ke dalam kategori sangat baik.

Menurut Nuako dalam (Setiono, S., Nuranti, G., \& Agustini, 2020) proses pembelajaran akan terjadi ketika peserta didik dapat berinteraksi, mengajukan pertanyaan-pertanyaan serta mengkonstruksi pengetahuan baru dari pengalaman yang didapat peserta didik dalam kehidupan sehari-hari dan pengetahuan awal peserta didik itu sendiri. Karplus \& Their dalam (Ngalimun, Muhammad Fauzani, 2018) mendefinisikan learning cycle adalah suatu model pembelajaran yang berpusat pada peserta belajar dan learning cycle merupakan rangkaian tahap-tahap kegiatan yang diorganisir sedemikian rupa sehingga peserta belajar dapat menguasai sejumlah kompetensi yang harus dicapai dalam pembelajaran melalui peran aktivitas peserta didik. Learning cycle juga merupakan model pembelajaran yang mengarahkan peserta didik untuk berperan aktif dalam pembelajaran, mengeksplor pengetahuan awalnya, dan membuktikan sendiri kebenaran pengetahuan awal tersebut (Nurbani et al., 2016). Pembelajaran daring yang dilakukan dengan model $9 E$ learning cycle at home dalam penelitian ini dipandu oleh guru secara online dengan cara mengirim file, foto dan video pembelajaran untuk peserta didik melalui WhatsApp Group. Moore, Dickson-Deane dan Galyen dalam (Gusty, 2020) mengungkapkan bahwa pembelajaran daring memiliki kekuatan, tantangan dan hambatan tersendiri. Kegiatan 
pembelajaran dengan materi pencemaran lingkungan menggunakan model $9 E$ learning cycle at home melalui pembelajaran daring untuk melatih keterampilan proses sains terjadi dalam 9 tahap yaitu: 1] tahap elicit yaitu guru menyapa dan memberi salam pada peserta didik melalui WhatsApp group, guru mengecek kehadiran peserta didik, guru menyampaikan tujuan dan manfaat mempelajarari pencemaran lingkungan, guru menginformasikan kegiatan yang akan dilaksanakan, guru menyampaikan pengetahuan awal pada pesera didik mengenai pencemaran lingkungan, 2] tahap engagement yaitu guru menyampaikan apersepsi, guru menarik perhatian peserta didik dengan meminta salah seorang peserta didik untuk berpendapat, guru memotivasi peserta didik, guru memastikan peserta didik sudah menyiapkan alat bahan untuk pembelajaran daring yang telahdiintruksikan sebelumnya, guru memastikan peserta didik sudah menyiapkan diri untuk mengikuti pembelajaran secara berkelompok sesuai dengan domisili terdekat yang terdiri dari 3-5 orang, 3] tahap explore, pada tahap ini terjadi proses melatih keterapilan proses sains dengan indicator mengamati yaitu guru memberikan materi pembelajaran baik itu berupa link pembelajaran, video, gambar ataupun ppt kemudian meminta peserta didik untuk mengamati.

Guru meminta peserta didik mencari informasi sebanyak banyaknya mengenai materi pembelajaran, selanjutnya guru mengarahkan peserta didik untuk bertanya. Guru membuka forum diskusi dan mempersilakan peserta didik untuk mencoba menjawab pertanyaan yang diajukan peserta didik lainnya untuk melatih keterapilan proses sains dengan indicator mengomunikasikan. Selanjutnya guru membagikan LKPD pada peserta didik, melalui LKPD guru akan mendorong peserta didik untuk mengetahui lebih lanjut tentang materi pembelajaran yang diberikan diantaranya mengenati pengertian dan macam-macam pencemaran lingkungan, kegiatan percobaan pencemaran, peyelidikan, dan selanjutnya membuat gagasan tentang pencemaran lingkungan. Pada LKPD ini telah mencakup semua indicator keterampilan proses sains yaitu mengamati, mengklasifikasi, mengukur, mengomunikasikan, menyimpulkan, memprediksi melalui kegiatan yang dilakukan, 4] tahap explain yaitu guru membimbing peserta didik untuk melakukan kegiatan diskusi kelompok dalam mengerjakan LKPD melalui Whatsapp group, guru mendorong siswa untuk menemukan istilah-istilah atau penjelasanpenjelasan yang tepat dalam mengerjakan LKPD, 5] tahap echo yaitu guru mengkonfirmasi penguasaan peserta didik atas konten yang diajarkan dan memberikan umpan balik atau bantuan jika diperlukan, 6] tahap elaborate yaitu guru memberikan link Google Meet pada peserta didik untuk masuk kepada kegiatan mempresentasikan hasil, guru meminta beberapa peserta didik (dipilih secara random) untuk mempresentasikan hasil pengerjaan LKPD, kegiatan ini untuk melatih keterapilan proses sains dengan indicator mengomunikasikan, 7] tahap evaluation yaitu guru memberikan soal evaluasi pada peserta didik, guru meminta peserta didik untuk mengumpulkan hasil evaluasi dan hasil pengerjaan LKPD di Whatsapp group, 8] tahap emendation yaitu guru meminta peserta didik untuk menyimpulkan hasil dan menjelaskan contoh penerapan konsep dari kegiatan yang telah dilakukan, kegiatan ini untuk melatih keterampilan proses sains dengan indicator menyimpulkan, selanjutnya guru memfokuskan pada pemahaman dan kemampuan belajar peserta didik dengan merefleksi/memperbaiki apa yang dikemukakan peserta didik, terakhir 9] tahap $E$ search yaitu berdasarkan data-data yang telah diperoleh dari pembelajan, guru meminta peserta didik untuk memprediksikan apa yang akan terjadi apabila pencemaran air dibiarkan dan tidak dicegah atau ditanggulangi, kegiatan ini untuk melatih keterapilan proses sains dengan indicator meprediksi. Tahap ini merupakan tahap yang terakhir dari 9E learning cycle at home melalui pembelajaran daring, peserta didik diminta untuk dapat menghubungkan semua tahap pada model dengan menggabungkan penggunaan teknologi dalam tata cara penyampaian 
pembelajaran.

Hasil penelitian menunjukkan bahwa keterampilan proses sains peserta didik perempuan lebih unggul dari peserta didik laki-laki berkaitan dengan proses pembelajarannya yang dilakukan. Ada perbedaan terhadap laki-laki dan perempuan dalam penggunaan otak saat berpikir. Rata-rata skor keterampilan proses sains peserta didik perempuan sedikit lebih tinggi dari pada rata-rata skor keterampilan proses sains peserta didik laki-laki, perbedaannya sangat tipis yaitu perempuan $94 \%$ dan lakilaki 90\%. Hamdani (Hamdani, 2017) menyebutkan bahwa gender tak mempengaruhi skor keterampilan proses sains mungkin disebabkan karena kesempatan yang sama pada peserta didik melakukan kegiatan praktikum di laboratorium.. Hasil penelitian lain yang dilakukan oleh Zeidan dan Jayosi (2015) pada penelitian Hamadi (2017) menunjukkan pada keterampilan proses sains siswa perempuan lebih unggul dibandingkan laki-laki. Pada penelitian lain yang dilakukan oleh Hindun Syarifah, Sri Endah Indriwati, Aloysius Duran Corebima menyebutkan bahwa peserta didik perempuan lebih unggul dalam keterampilan dibandingkan peserta didik laki-laki. Hal ini dapat dijelaskan bahwasecara biologis, perbedaan beberapa struktur otak memungkinkan siswa laki-laki dan siswa perempuan berbeda dalam beberapa hal seperti kemampuan memproses, menanggapi informasi, atau menyimpan informasi jangka panjang. Sasser dalam (Syarifah et al., 2016) melaporkan daerah sistem limbik pada laki-laki dan perempuan memiliki struktur yang berbeda.

Lebih lanjut dijelaskan bahwa perempuan umumnya memiliki hippocampus lebih besar daripada laki-laki, sehingga berpotensi meningkatkan memori penyimpanan jangka panjang yang lebih baik. Selain itu, bagian otak lain yang memiliki struktur berbeda antara laki-laki dan perempuan adalah bagian cerebral cortex yang mengontrol berpikir, pengambilan keputusan, dan fungsi intelektual. Otak perempuan menerima sekitar $20 \%$ lebih banyak aliran darah dan memiliki koneksi saraf yang lebih banyak. Menurut Witelson, dkk dalam (Syarifah et al., 2016) mengatakan bahwa hal tersebut memungkinkan perempuan dapat memproses danmenanggapi informasi yang lebih cepat.

Hasil belajar adalah kemampuan-kemampuan yang dimiliki peserta didik setelah menerima pengalaman belajarnya (Sudjana, 2010). Hasil peningkatan ini berkaitan dengan hal yang diungkapkan oleh Abraham dalam (Adilah \& Budiharti, 2015) bahwa, "the learning cycle model derived from constructivist ideas of the nature of science, and the development theory of Jean Piaget". Ketercapaian keterampilan proses sains peserta didik pada penelitian ini adalah hasil dari diterapkannya model $9 E$ learning cycle at home. Model $9 E$ learning cycle merupakan pengembangan dari model 7E learningcycle yang berisi serangkaian sembilan fase yang direncanakan dan saling berhubungan dimana peserta didik menempuh berbagai keilmuan investigasi dengan mengeksplorasi bahan ajar, membangun konsep setelah sampai pada kesimpulan dan menerapkan konsep atau prinsip yang telah dipegang teguh masalah baru sehingga menanamkan rasa belajar dengan merangsang keinginan siswa untuk mengeksplorasi, berpikir, dan memperoleh pengalaman (Tukiran et al., 2020). WhatsApp group dipilih sebagai salah satu media pembelajaran, karena ditinjau dari sisi jumlah pengguna, fungsi dancara penggunaannya, dimana pendidik dapat berbagi (sharing) materi pelajaran atau tugas dalam bentuk gambar, pdf, ppt, doc, xls, audio, video secara langsung dan meminta tanggapan (jawaban) dari peserta grup (peserta didik). Barhoumi menyebutkan pembelajaran menggunakan aplikasi grup WhatsApp membawa manfaat bagi prestasi dan sikap peserta didik terhadap pembelajaran dan pendidikan secara mobile (Pustikayasa, 2019). 


\section{SIMPULAN}

Berdasarkan hasil penelitian yang telah dilakukan, maka dapat disimpulkan bahwa peningkatan $\mathrm{N}$ Gain keterampilan proses sains peserta didik dengan penerapan model $9 E$ learning cycle at home melaluipembelajaran daring dalam pembelajaran IPA materi pencemaran lingkungan termasuk dalam kategori tinggi yaitu dengan presentase $84 \%$. Keterampilan proses sains tertinggi terdapat pada indikator 4 yaitu mengomunikasikan dengan perolehan presentase sebesar $97 \%$ dan pencapaian terendah pada indikator 2 yaitu mengklasifikasikan dengan perolehan presentase sebesar $71 \%$. Keterampilan proses sains peserta didik perempuan lebih unggul dari peserta didik laki-laki dimana peserta didik perempuan memperoleh nilai rata-rata presentase sebesar $94 \%$ sedangakan peserta didik laki-laki memperoleh nilai rata- rata presentase sebesar 90\%. Maka penggunaan model ini dapat menjadi pertimbangan peneliti selanjutnya dalam pendidikan IPA.

\section{UCAPAN TERIMAKASIH}

Puji serta syukur kepada Allah WST dan juga kepada semua pihak yang telah membantu dalam menyelesaikan penelitian dan menuliskan artikel ilmiah yang berjudul "Profil Keterampilan Proses Sains Peserta Didik Menggunakan Model Pembelajaran 9E Learning Cycle at Home Melalui Pembelajaran Daring". Terima kasih kepada kepala MTs Persatuan Islam 04 Cianjur yang telah mengizinkan untuk melakukan penelitian di sekolah tersebut. Ucapan terima kasih juga kepada semua pihak yang sudah mendukung dan men-support untuk menyelesaikan penelitian ini.

\section{RUJUKAN}

A Mulyana. (2020). Pengertian penelitian eksperimen dan karakteristik penelitian eksperimen. Pengertian Penelitian Eksperimen Dan Karakteristik Penelitian Eksperimen. https://ainamulyana.blogspot.com/2019/07/pengertian-penelitian-eksperimen-dan.html

Adilah, D. N., \& Budiharti, R. (2015). Model Learning Cycle 7E Dalam Pembelajaran IPA Terpadu. Prosiding Seminar Nasional Fisika Dan Pendidikan Fisika (SNFPF) Ke-6, 6, 212-217.

Ai Hayati Rahayu \& Poppy Anggraeni. (2017). Analisis Profil Keterampilan Proses Sains Siswa Sekolah Dasar Di Kabupaten Sumedang. Pesona Dasar (Jurnal Pendidikan Dasar Dan Humaniora), 2, 22- 33. https://doi.org/10.24815/pear.v7i2.14753

Andani, M., \& Utami, L. (2019). Pengaruh Penerapan Model Pembelajaran Learning Cycle 7E terhadap Keterampilan Proses Sains Siswa pada Materi Koloid di SMA Negeri 10 Pekanbaru. Journal of Natural Science and Integration, 2(1), 54. https://doi.org/10.24014/jnsi.v2i1.7114

Buwono, iffah S., Kartono, \& Asih, T. S. N. (2020). Peran Kid- Friendly "Rubrics" dalam Model Pembelajaran 9E Learning Cycle Terhadap Kemampuan Penalaran Matematis Siswa. PRISMA,Prosiding Seminar Nasional Matematika, 3, 621-625.

Dewi, N. P. S. R., Wibawa, I. M. C., \& Devi, N. L. P. L. (2017). Kemampuan Berpikir Kritis Dan Keterampilan Proses Dalam Pembelajaran Siklus Belajar 7E Berbasis Kearifan Lokal. JPI (Jurnal Pendidikan Indonesia), 6(1), 125-133. https://doi.org/10.23887/jpi-undiksha.v6i1.9476

Ganda Noor Andaru, M. Rendi Astono Sentosa, D. S. et al. (2019). Pengaruh Model Pembelajaran Learning Cycle 7E Terhadap Keterampilan Proses Sains Siswa Pada Mata Pelajaran Fisika 
Pokok Bahasan Vektor Kelas X MIPA MAN 1 Cirebon. JPFS, 7(1), 51-55. https://doi.org/10.24114/inpafi.v7i1.13507

Gusty, S. (2020). Belajar Mandiri: Pembelajaran Daring di Tengah Pandemi Covid-19. Yayasan Kita Menulis.

Hamdani. (2017). Deskripsi Keterampilan Proses Sains. Jurnal Pendidikan Matematika Dan IPA, 8(1), 4351.

Kemendikbud. (2020). Peta Jalan Pendidikan Indonesia. Kemendikbud. (2020). Peta Jalan Pendidikan Indonesia 2020-2035. http://abpptsi.org/2020/12/peta-jalan-pendidikan-indonesia-2020-2035/

Lesmana Sari, E., Billyardi Ramdhan, \& Sistiana Windyariani. (2020). Beban Kognitif Siswa Pada Materi Pencemaran Lingkungan Berbantuan Prezi Application. Biodik, 6(3), 233-243. https://doi.org/10.22437/bio.v6i3.9840

Ngalimun, Muhammad Fauzani, A. S. (2018). Strategi dan Model Pembelajaran. Strategi Dan Model Pembelajaran, Yogyakarta: AswajaPressindo, 145. https://opac.perpusnas.go.id/DetailOpac.aspx?id=1152879

Niko Ramdhani. (2020). Pentingnya Memahami Fungsi dan Tujuan dari Pendidikan. https://www.akseleran.co.id/blog/pendidikan-adalah/

Nirmalasari, Santiani, H. M. R. (2016). PENERAPAN MODEL PEMBELAJARAN LEARNING CYCLE TERHADAP KETERAMPILAN PROSES SAINS DAN HASIL BELAJAR SISWA PADA POKOK BAHASAN GETARAN HARMONIS. PENERAPAN MODEL PEMBELAJARAN LEARNING CYCLE TERHADAP KETERAMPILAN PROSES SAINS DAN HASIL BELAJAR SISWA PADA POKOK BAHASAN GETARAN HARMONIS, 4(3), 74-94.

Nurbani, D., Gusrayani, D., \& Jayadinata, A. K. (2016). Pengaruh Model Learning Cycle Terhadap Keterampilan Proses Sains Siswa Sd Kelas Iv Pada Materi Hubungan Antara Sifat Bahan Dengan Kegunaannya. Jurnal Pena IImiah, 1(1), 211-220. https://doi.org/10.23819/pi.v1i1.3301

P. Kaur \& A. Gakhar. (2014). 9E model and e-learning methodologies for the optimisation of teaching and learning. Innovation and Technology in Education (MITE). IEEE International Conference. https://www.semanticscholar.org/paper/9E-model-and-e-learning-methodologies-for-the-of-KaurGakhar/a0320baf669ada925c8b708cc7bac1397d8e5d8e

Pustikayasa, I. M. (2019). Grup WhatsApp Sebagai Media Pembelajaran. Widya Genitri : Jurnal IImiah Pendidikan, Agama Dan Kebudayaan Hindu, 10(2), 53-62. https://doi.org/10.36417/widyagenitri.v10i2.281

Rahmah, Y., Muh. Nasir, \& Nikman Azmin. (2019). Penerapan Model Pembelajaran 5E Untuk Meningkatkan Keterampilan Proses Sains Dan Sikap IImiah Siswa Kelas VIII SMP NEGRI 6 KOTA Bima. ORYZA Jurnal Pendidikan Biologi, 1337, 4046.http://jurnal.stkipbima.ac.id/index.php/OZ/article/view/296

Saraç, H. (2018). The Effect Of Learning Cycle Models Usage On Students' Permanence Of The Learned Information: A Meta-Analysis Study. Kastamonu Eğitim Dergisi, 4(1), 1-10. https://doi.org/10.24106/kefdergi.413322

Sayuti, I., Rosmaini, S., \& Andayannhi, S. (2013). Penerapan Model Pembelajaran Learning Cycle 5E Untuk Meningkatkan Sikap IImiah Dan Hasil Belajar Biologi Siswa Kelas XI IPA 4 SMA 
Negeri 5Pekanbaru. Jurnal Pendidikan, 3(1), 1-11.

Setiono, S., Nuranti, G., \& Agustini, M. M. (2020). Meningkatkan Hasil Belajar Peserta Didik Melalui Aktivitas Saintifik Dan Visualisasi. Jurnal Pendidikan Sains (Jps), 8(1). https://doi.org/10.26714/jps.8.1.2020.27-31

Setiono, S., Rustaman, N. Y., Rahmat, A., \& Anggraeni, S. (2019). Student's inquiry skills and learning achievement in plant anatomy practical work using open-guided inquiry. Journal of Physics: Conference Series, 1157(2), 6-12. https://doi.org/10.1088/1742-6596/1157/2/022089

Suardana, I. N., Redhana, I. W., Sudiatmika, A. A. I. A. R., \& Selamat, I. N. (2018). Students' critical thinking skills in chemistry learning using local culture- based $7 E$ learning cycle model. International Journal of Instruction, 11(2), 399.

Sudjana, N. (2010). Penilaian Hasil Belajar Mengajar. Penilaian Hasil Belajar Mengajar, 22. https://doi.org/Bandung: Rosdakarya

Sugiyono. (2018). Metode Penelitian Kuantitatif, Kualitatif dan R\&D.

Syarifah, H., Indriwati, S. E., \& Corebima, A. D. (2016). Pengaruh Strategi Pembelajaran Reading Questioning and Answering (RQA) Dipadu Think Pair Share (TPS) terhadap Keterampilan Metakognitif Siswa Laki-Laki dan Perempuan SMA Di Kota Malang. Teori, Penelitian, Dan Pengembangan, 1(5), 801-805.

Tukiran, Mubarokah, F. A., \& Nasrudin, H. (2020). Improvement of Self-Efficacy and Student LearningOutcomes on Acid Base Material Using 9E Learning Cycle Model. 196(ljcse), 199202. https://doi.org/10.2991/aer.k.201124.037

Yaman, S., \& Karaşah, Ş. (2018). Effects of Learning Cycle Models on Science Success: a Meta-Analysis Issn 1648-3898 Issn 2538-7138. Journal of Baltic Science Education, 17(1), 65-83. 